\title{
SISTEM KRAN AIR OTOMATIS MENGGUNAKAN SENSOR INFRARED AJDUSTABLE
}

\author{
Muhammad Faisal $^{1}$, Rika Wahyuni Arsianti ${ }^{2}$
}

\author{
${ }^{1,}$ Mahasiswa Teknik Elektro Universitas Borneo Tarakan, Tarakan, Kalimantan Utara,Indonesia \\ 2, Teknik Elektro Universitas Borneo Tarakan, Tarakan, Kalimantan Utara,Indonesia \\ rkwahyuni@gmail.com
}

\begin{abstract}
Water is a natural resource that must be protected. The greater the population, the need for water also increases. The amount of water reserves cannot serve the water needs of the community during the dry season. Therefore, one way to overcome this situation is to optimize the use of water. The purpose of this research is to make an automatic faucet to save water usage. This research uses an infrared adjustable sensor to detect objects to open and close water faucets. This automatic water tap system will be tested on ablution water collection to determine the amount of water savings that can be achieved. The number of samples in this study is 10 subjects where each sample will perform ablution with ordinary faucets and using automatic water faucets. The data from two types of faucets will be compare to measure the efficiency of water use. The results show that the average water use for ablution is 10 liters of water and 7.2 liters of water for automatic faucet systems. Automatic water faucet system can save water usage by $30 \%$. This shows that the use of an automatic water tap system works well to save water usage. If the use of an automatic water tap system is carried out on a larger scale, this can certainly save greater water needs. This automatic water faucet system is able to be one of the solutions of local governments in efforts to meet the water needs of the community.
\end{abstract}

Keywords - arduino, infrared adjustable, selenoid valve, water

Intisari-Air merupakan sumber daya alam yang harus dijaga. Kebutuhan air semakin meningkat seiring dengan jumlah penduduk yang semakin besar. Sehingga ketika musim kemarau tiba cadangan air menjadi tidak sesuai dengan jumlah kebutuhan air. Oleh karena itu salah satu cara untuk mengatasi keadaan tersebut adalah mengoptimalkan pemakaian air. Tujuan dari penelitian ini adalah membuat kran otomatis untuk menghemat pemakaian air. Penelitian ini menggunakan sensor infrared adjustable untuk mendeteksi objek untuk mengatur kran air. Sistem kran air otomatis ini akan diujicobakan pada pengambilan air wudhu untuk diketahui jumlah penghematan air yang dapat dicapai. Jumlah sampel pada penelitian ini sebanyak 10 orang dimana tiap sampel akan melakukan intervensi wudhu dengan kran biasa dan wudhu menggunakan kran air otomatis untuk dilihat efisiensi penggunaan air. Dari hasil penelitian rata-rata penggunaan air untuk berwudhu adalah 2 liter air. Sedangkan rata-rata penggunaan air untuk 10 sample adalah 7.2 liter air. Sistem kran air otomatis dapat menghemat penggunaan air sebesar $30 \%$. Ini menunjukkan penggunaan sistem bekerja dengan baik untuk menghemat penggunaan air. Jika penggunaan sistem kran air otomatis dilakukan dalam skala yang lebih besar tentu dapat menghemat kebutuhan air yang semakin besar. Sistem kran airotomatis mampu menjadi salah satu solusi pemerintah daerah dalam upaya pemenuhan kebutuhan air masyarakat.

Kata Kunci-air, arduino,infrared adjustable, selenoid valve

\section{PENDAhuluan}

Tingginya tingkat kebutuhan manusia terhadap air tidaklah sebanding dengan ketersediaan air di bumi, karena dari seluruh air yang ada di bumi $97 \%$ adalah air laut, $3 \%$ sisanya adalah air tawar dan hanya $1 \%$ saja yang tersedia untuk digunakan seluruh manusia.Banyaknya pemborosan penggunaan air menyebabkan terjadinya pemborosan pemakaian air. Hingga saat ini tingkat kebutuhan air semakin tinggi seiring dengan semakin tingginya tingkat pertambahan penduduk dunia. UNESCO memprediksikan bahwa pada tahun 2020 dunia akan mengalami krisis air global.

Kota Tarakan dengan jumlah penduduk 200.000 jiwa memiliki 5 embung yakni Embung Persemayam dengan kapasitas $250.000 \mathrm{~m}^{3}$, Embung Binalatung dengan kapasitas $450.00 \mathrm{~m}^{3}$, Embung Bengawan $148.00 \mathrm{~m}^{3}$, Embung Rawasari $112.00 \mathrm{~m}^{3}$ dan Embung Indalung $123.00 \mathrm{~m}^{3}$ [1]. Debit pengambilan sebesar 250 liter per detik, utamanya untuk memenuhi kebutuhan air baku domestik dan industri, kebutuhan air penduduk Tarakan yaitu 900 liter per detik yang diperuntukkan bagi 200.000 jiwa masyarakat. Sementara, kebutuhan yang baru dapat terpenuhi yakni 400 liter per detik [2]. Penggunaan air dalam jumlah tersebut tidaklah sesuai dengan ketersediaan air [3]. Sehingga dibutuhkan cara untuk penghematan penggunaan air

Tujuan penelitian ini adalah mengontrol penggunaan air menggunakan sensor infrared adjustable berbasis mikrokontroler. Pada penelitian ini penghematan air dilakukan pada kegiatan wudhu.

Beberapa penelitian tentang penggunaan kran otomatis untuk penghematan air dilakukan oleh Suhardi menggunakan sensor ultrasonic [4] yang diterapkan pada kran bak mandi. Penelitian tentang kran ototmatis juga dilakukan untuk kegiatan wudhu menggunakan sensor ultrasonic $[5,6,7,8]$. Basari pada penelitiannya menggunakan sensor kamera untuk mengontrol kran untuk berwudhu [9].

Namun penelitian sebelumnya tidak menghitung berapa penghematan air yang diperoleh. Pada penelitian ini digunakan sensor infrared adjustable sebagai pengatur kran dan menghitung penghematan dalam penggunaan air dalam kegiatan berwudhu.

\section{LANDASAN TEORI}

\subsection{Sensor Infrared Adjustable}

Sensor infrared adjustable merupakan salah satu sensor infra merah yang mana keadaannya berupa nilai digital yaitu high dan low. Sensor ini dapat dikatakan 
bekerja apabila keadaannya low. Jika objek mendekati sensor maka output sensor akan bernilai low. Pada dasarnya sensor ini sebenarnya sama dengan sensor infra merah yang lain. walaupun cahaya infra merah mempunyai panjang gelombang yang sangat panjang tetapi tetap tidak dapat menembus bahan-bahan yang tidak dapat melewatkan cahaya yang nampak, sehingga cahaya infra merah tetap mempunyai karakteristik seperti halnya cahaya yang nampak oleh mata.

Sensor inframerah digunakan sebagai sensor pengukur jarak, dimana nilai akurasi lebih tinggi jika jarak objek pada range $20 \mathrm{~cm} \leq \mathrm{x} \leq 150 \mathrm{~cm}$ [10]. Penelitian tentang sensor infrared sebagai pengukur jarak juga menghasilkan kesimpulan bahwa sensor infrared mampu mendeteksi objek pada jarak lebih dari 1 meter [11].

\subsection{Selenoid Valve}

Solenoid valve merupakan katup yang dikendalikan dengan arus listrik baik AC maupun DC melalui kumparan / selenoida. Solenoid valve ini merupakan elemen kontrol yang paling sering digunakan dalam sistem fluida seperti pada tendon air yang membutuhkan solenoid valve sebagai pengatur pengisian air, sehingga tandon tersebut tidak sampai kosong. solenoid valve ini di desain sesuai dari kegunaannya. Pada penelitian ini solenoid valve yang digunakan yaitu solenoid valve 2 saluran yang sering disebut katup kontrol arah. Jadi fungsinya hanya membuka dan menutup saluran karena hanya memiliki 1 lubang inlet dan outlet. Inlet berfungsi sebagai masuknya fluida dan outlet berfungsi sebagai keluaran fluida dan exhaust berfungsi sebagai saluran pembuangan fluida yang terjebak.

Selenoid valve AC digunakan untuk system kran air otomatis dengan sensor floatless [12]. Pada system yang membutuhkan respon system yang cepat solenoid yang digunakan adalah solenoid valve AC dimana waktu respon nya sekitar 5 - $8 \mu$ s sedangkan solenoid valve dc memiliki respon waktu 30-40 $\mu$ s.

\section{METODE PENELITIAN}

Diagram blok kran air otomatis dapat dilihat pada gambar 1. Sensor infrared adjustable akan mengirimkan data ke mikrokontroler jika terdapat objek yang terdeteksi. Sudut kerja sensor diatur sebesar $15^{0}$ untuk membatasi objek yang akan dideteksi oleh sensor. Hal ini dimaksudkan agar tidak semua benda yang berada disekitar sensor dideteksi. Hanya yang berada pada sudut $15^{0}$ yang akan dideteksi. Pada penelitian ini kran air otomatis di implementasikan pada kran air wudhu. Sehingga pengaturan jarak objek yang dapat di deteksi oleh sensor diatur pada jarak $45 \mathrm{~cm}$. Jika jarak objek yang dideteksi < $45 \mathrm{~cm}$ maka mikrokontroler akan mengaktifkan relay untuk menggerakkan solenoid valve membuka katup kran. Jika jarak objek yang dideteksi > $45 \mathrm{~cm}$ maka sensor tidak mengirimkan data dan mikrokontroler akan kembali pada proses inisiasi.

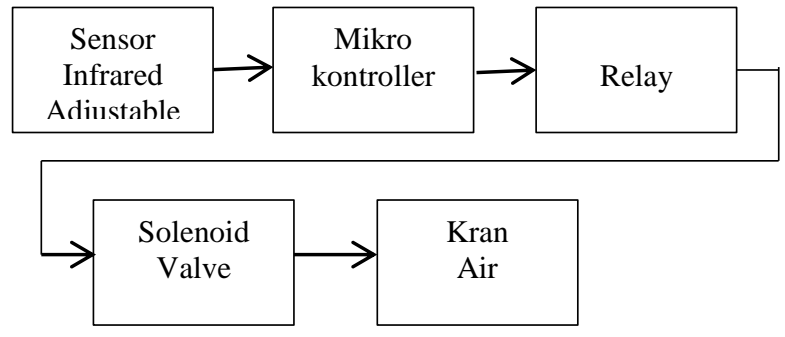

Gambar 3.1 Diagram blok kran air otomatis

Adapun prinsip kerja sistem kran otomatis sebagai berikut:

- Apabila tangan sudah berada tepat pada sensor maksimal $45 \mathrm{~cm}$ maka air kran akan mengalir. Namun apabila tangan tidak berada tepat pada sensor serta pada jarak melebihi $45 \mathrm{~cm}$ maka sensor tidak biasa mendeteksi dan kran tidak akan mengalir

- Selama tangan berada tepat dibawa sensor maka sensor akan terus mendeteksi dan secara terus menerus air juga akan selalu mengalir.

\subsection{Desain Mekanik Kran Air Otomatis}

Desain perancangan mekanik kran air otomatis dapat dilihat pada gambar 3.2. Tinggi penampungan air dari lantai adalah $90 \mathrm{~cm}$. Sensor dirancang bekerja dengan jarak maksimal $45 \mathrm{~cm}$ yang disesuaikan dengan kebutuhan pengambilan air wudhu.

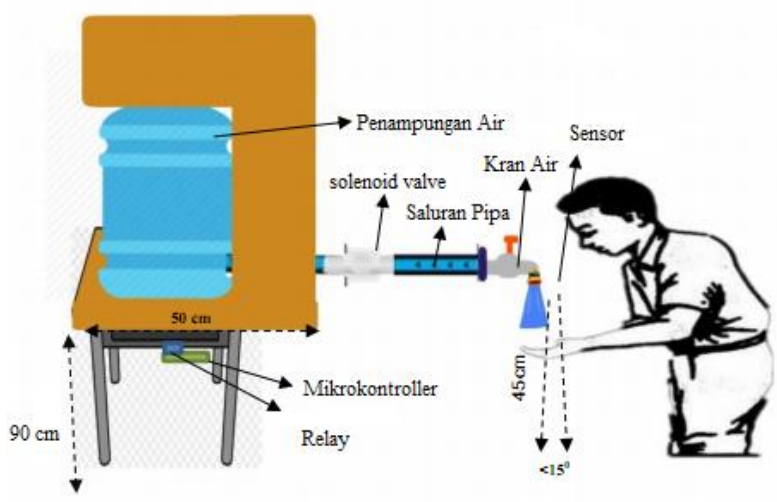

Gambar 3.2 Desain Mekanik Kran Air

\subsection{Experimental Set- $U p$}

Jumlah sampel pada penelitian ini sebanyak 10 orang. Pada eksperimen pertama subjek akan melakukan pengambilan air wudhu dengan kran manual. Data penggunaan volume air wudhu akan dicatat. Setelah itu subjek akan melakukan pengambilan air wudhu pada kran air otomatis. Dan akan dicatat jumlah penggunaan air. Data penggunaan air dengan menggunakan kran air manual dan otomatis akan dibandingkan untuk melihat efisiensi yang dapat diperoleh. Persamaan efisiensi penggunaan air wudhu diperoleh melalui persamaan (1).

$t=100-\left(\frac{K_{O}}{K_{M}} \times 100 \%\right)$

dimana

$\mathrm{t}=$ efisiensi penggunaan air

$\mathrm{K}_{\mathrm{O}}=$ kran air menggunakan sensor

$\mathrm{K}_{\mathrm{M}}=$ kran air tanpa sensor 
Tata cara berwudhu pada penelitian ini dilakukan dengan urutan membasuh telapak tangan, membersihkan mulut (kumur-kumur), membasuh hidung kemudian wajah, tangan hingga siku, mengusap bagian depan kepala, membasuh telinga dan menyiram kaki. Dengan tiap gerakan dilakukan pengulangan sebanyak 3 kali.

Untuk setiap pengambilan data penggunaan air untuk berwudhu dilakukan dengan cara memberi level air pada wadah. Pada penelitian ini wadah air yang digunakan memiliki kapasitas 10 liter air. Untuk setiap percobaan wadah air diisi sebesar 5 liter air. Setelah subjek berwudhu maka akan dihitung volume air yang tersisa pada wadah.

\section{HASIL DAN PEMBAHASAN}

\section{A. Pengujian Sensor}

Sensor infrared adjustable akan bekerja dan mendeteksi ketika objek berada tepat pada sensor sejajar horizontal dengan jarak yang telah ditentukan sesuai perancangan $5 \mathrm{~cm}-45 \mathrm{~cm}$. Ketika sensor mendeteksi objek maka arduino akan mengaktifkan modul relay dan solenoid valve akan aktif. Jika objek melebihi dari batas jarak $45 \mathrm{~cm}$ maka sensor tidak akan bekerja. Hasil pengujian tegangan keluaran sensor dapat dilihat pada tabel 1 .

Tabel I. Data pengujian tegangan sensor

\begin{tabular}{|c|c|c|}
\hline \multirow{2}{*}{ No } & \multicolumn{2}{|c|}{ Tegangan (V) } \\
\cline { 2 - 3 } & Sensor Bekerja & Sensor Tidak Bekerja \\
\hline 1 & 0.688 & 3.480 \\
\hline 2 & 0.687 & 3.480 \\
\hline 3 & 0.688 & 3.490 \\
\hline 4 & 0.688 & 3.480 \\
\hline 5 & 0.688 & 3.480 \\
\hline
\end{tabular}

Dari tabel 1 dapat dilihat bahwa sensor bekerja pada tegangan $0.68 \mathrm{~V}$ (kondisi Low) dan tegangan keluaran saat sensor tidak bekerja adalah $3.48 \mathrm{~V}$. Pengukuran tegangan keluaran sensor ini dilakukan pengulangan sebanyak 5 kali. Hasilnya menunjukkan bahwa tegangan sensor tetap stabil pada tegangan $0.68 \mathrm{~V}$ yang artinya telah sesuai dengan spesifikasi cara kerja sensor. Langkah selanjutnya adalah menguji coba sensor berdasarkan jarak deteksi. Jarak deteksi objek yaitu $5 \mathrm{~cm}$ hingga $45 \mathrm{~cm}$ seperti yang ditunjukkan pada tabel II.

Tabel II. Pengujian jangkauan sensor

\begin{tabular}{|c|c|}
\hline Jarak sensor $(\mathrm{cm})$ & Selenoid Valve \\
\hline 5 & Terbuka \\
\hline 10 & Terbuka \\
\hline 25 & Terbuka \\
\hline 30 & Terbuka \\
\hline 40 & Terbuka \\
\hline 45 & Tertutup \\
\hline 50 & Tertutup \\
\hline 70 & Tertutup \\
\hline 90 & Tertutup \\
\hline
\end{tabular}

Tabel II menunjukkan bahwa sensor telah bekerja sesuai jarak yang ditentukan. Jarak $5 \mathrm{~cm}-45 \mathrm{~cm}$ katup terbuka dan pada jarak $>50 \mathrm{~cm}$ katup tertutup. Pada jarak sensor $5 \mathrm{~cm}-45 \mathrm{~cm}$ sensor memberikan data "Low" pada mikrokontroller sebesar $0.68 \mathrm{~V}$ sehingga katup akan membuka. Pada jarak sensor $>45 \mathrm{~cm}$ sensor akan memberikan data "High" sebesar 3.49 V ke mikrokontroller. Pada level tegangan ini mikro tidak memerintahkan relay bekerja sehingga katup tertutup.

\section{B. Pengujian Selenoid Valve}

Pengujian Solenoid Valve dengan catu daya $12 \mathrm{~V}$ untu membuka (ON) dan menutup (OFF) katup. Tegangan keluaran solenoid valve saat membuka dan menutup katup dapat dilihat pada gambar 3 dan 4. Tegangan saat Solenoid Valve On adalah 11.05 Volt sedangkan pada saat Off 0 Volt.

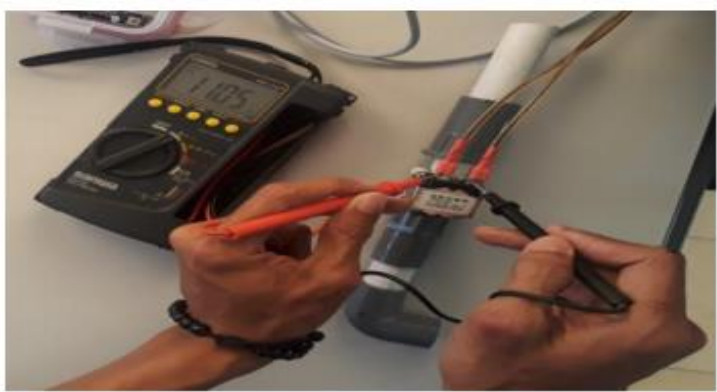

Gambar 3. Tegangan Solenoid Valve saat ON

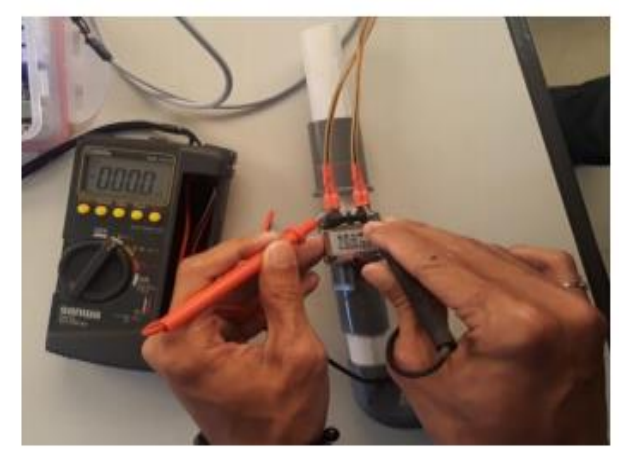

Gambar 4. Tegangan Solenoid Valve saat Off

\section{Pengujian Modul Relay}

Mikrokontroller akan memberikan tegangan ke relay untuk mengaktifkan relay. Data tegangan relay dapat dilihat pada tabel III.

Tabel III. Pengukuran tegangan relay

\begin{tabular}{|c|c|c|}
\hline \multirow{2}{*}{ No } & \multicolumn{2}{|c|}{ Tegangan (V) } \\
\cline { 2 - 3 } & Relay Aktif & Relay Tidak Aktif \\
\hline 1 & 0.67 & 4.82 \\
\hline 2 & 0.67 & 4.80 \\
\hline 3 & 0.68 & 4.78 \\
\hline 4 & 0.67 & 4.82 \\
\hline 5 & 0.67 & 4.80 \\
\hline
\end{tabular}

Prinsip kerja relay yaitu apabila kumparan diberi energi listrik, maka akan muncul gaya elektromagnetik yang dapat menarik armature sehingga dapat berpindah dari posisi sebelumnya Normaly Open (NO) menjadi posisi baru yakni Normaly Close (NC). Ketika Arduino memberikan perintah high maka relay akan memicu 
kontaktor dengan tegangan kerja $4,78 \mathrm{~V}$ dan otomatis akan mengaktifkan solenoid valve, dan ketika Arduino memberikan perintah low maka relay tidak mendapatkan tegangan dan tidak bisa memicu kontakor yang hanya mendapatkan tegangan $0,67 \mathrm{~V}$ dan tidak dapat mengaktifkan solenoid valve.

D. Pengujian Sistem Kran Air Otomatis

Untuk mengetahui kinerja sistem kran air otomatis dengan sensor infrared adjustable maka 10 sampel melakukan wudhu dengan kran manual dank ran air otomatis. Hasil penggunaan air wudhu dengan dua jenis kran air dapat dilihat pada tabel IV.

Tabel IV. Data penggunaan air wudhu

\begin{tabular}{|c|c|c|c|}
\hline \multicolumn{2}{|c|}{ Kran tanpa Sensor } & \multicolumn{2}{c|}{ Kran dengan Sensor } \\
\hline Subjek & Volume (L) & Subjek & Volume (L) \\
\hline 1 & 2.2 & 1 & 1.5 \\
\hline 2 & 2.2 & 2 & 1.7 \\
\hline 3 & 2.1 & 3 & 1.5 \\
\hline 4 & 2.0 & 4 & 1.6 \\
\hline 5 & 2.2 & 5 & 1.2 \\
\hline 6 & 2.2 & 6 & 1.2 \\
\hline 7 & 2.1 & 7 & 1.4 \\
\hline 8 & 2.0 & 8 & 1.5 \\
\hline 9 & 1.8 & 9 & 1.4 \\
\hline 10 & 2.1 & 10 & 1.5 \\
\hline Total & $\mathbf{2 . 0 9}$ & Total & $\mathbf{1 . 4 5}$ \\
\hline
\end{tabular}

Dari table IV dapat dihitung penghematan air yang dapat dilakukan dengan menggunakan sensor infrared adjustable menggunakan persamaan (1).

$$
\begin{aligned}
& t=100-\left(\frac{K_{O}}{K_{M}} \times 100 \%\right) \\
& t=100-\left(\frac{1.45}{2.09} \times 100 \%\right) \\
& \mathrm{t}=30.62 \%
\end{aligned}
$$

Hasil penghematan penggunaan air untuk kegiatan wudhu dengan dan tanpa sensor dapat dilihat pada gambar 5. Volume penggunaan air untuk wudhu untuk kran tanpa sensor membutuhkan 2.09 Liter air sedangkan dengan menggunakan kran dengan sensor turun menjadi 1.45 liter air. Penghematan air liter sebanyak 0.64 liter air untuk satu waktu sholat. Proses penghematan air saat wudhu terjadi saat subjek sedang melakukan kumur-kumur dan membasuh anggota tubuh. Umat muslim melaksanakan sholat wajib sebanyak 5 waktu. Sehingga dalam melaksanakan wudhu untuk sholat wajib dari 10 subjek dapat menghemat air sebanyak 3.2 liter air.

Penelitian yang dilakukan oleh $\mathrm{R}$ Saputra menggunakan sensor ultrasonic pada sistem kran air otomatis membandingkan ketelitian sistem dalam membaca jarak objek yang di deteksi. [4]. Pada penelitian nya jarak maksimum yang dideteksi sensor adalah $30 \mathrm{~cm}$. Hasil dari penelitian ini menunjukkan bahwa error yang diperoleh sebesar $3.14 \%$.

Penelitian sejenis juga dilakukan oleh Hulukati yang menggunakan sensor ultrasonic ping. Hasilnya menunjukkan katup dan membuka dan menutup kran air jika terdapat objek yang dideteksi [5]. Namun tidak menunjukkan penghematan air yang dapat diperoleh melalui sistem kran air otomatis.

Penggunaan kran air otomatis pada bak mandi menggunakan sensor ultrasonic juga telah dilakukan untuk menghemat penggunaan air di rumah tangga [6]. Penelitian ini menggunakan motor servo untuk membuka dan menutup kran. Besari membuat system kran air otomatis menggunakan sensor kamera [7]. Jika kamera mendeteksi ada objek maka kran akan terbuka. Namun penelitian ini tidak menghitung jumlah air yang dapat dihemat.

Penggunaan kran air otomatis juga digunakan pada system penyiram tanaman dengan menggunakan sensor suhu dan kelembaban. [13], pada ketinggian level air [14] yang semuanyapenelitian tersebut bertujuan untuk mencegah pemborosan air.

Kran air otomatis dengan sensor infrared pada penelitian ini telah berhasil menghemat air sebesar $30 \%$. Jika sistem kran air ini dipasang pada masjid-mesjid maka penghematan air yang diperoleh tentu akan lebih besar. Penggunaan system ini juga menghindari pemborosan air yang disebabkan kelalaian pengguna kran untuk menutup kembali kran setelah digunakan, harganya relative murah dan mudah dalam pemasangan system kran air otomatis. Keuntungan lain dari penggunaan system kran air otomatis adalah menghindari rusaknya kran karena sering dibuka dan ditutup.

\section{KESIMPULAN}

Dari hasil penelitian ini menunjukkan bahwa sistem kran air otomatis dengan sensor infrared telah berhasil melakukan penghematan penggunaan air wudhu sebesar $30 \%$. Selain untuk berwudhu sistem kran air otomatis ini juga dapat diterapkan pada rumah tangga untuk memperoleh penghematan penggunaan air dalam skala yang lebuh besar. Penggunaan daya listrik pada sistem ini tidak besar sehingga dapat diterapkan pada masjid-mesij.

\section{UCAPAN TERIMA KASIH}

Ucapan terimakasih yang sebesar-besarnya pada partisipan yang telah bersedia membantu pada pengambilan data. Terutama kepada kedua orangtua yang telah mendukung selesainya projek ini.

\section{REFERENSI}

[1] www.pu.go.id 2017

[2] Dani, Prabowo. 2017. "Penuhi Kebutuhan Air, Pemerintah Bangun Dua Embung Di Tarakan." www.kompas.com.

[3] Astari, Sutris, Rozeff Pramana, and Deny Nusyirwan. 2013. "Kran Air Wudhu' Otomatis Berbasis Arduino Atmega 328." (0071).

[4] Suhardi,2019. Keran Air Otomatis Pada Bak Mandi Berbasis Arduino Uno Menggunakan Sensor Ultrasonic. Jurnal Ilmu Komputer dan Informatika Vol 3 (1).

[5] Shaputra, R., 2019. KRAN AIR OTOMATIS PADA TEMPAT BERWUDHU MENGGUNAKAN SENSOR ULTRASONIK BERBASIS ARDUINO UNO. SIGMA TEKNIKA, 2(2).

[6] Hulukaati SA,2018. RANCANG BANGUN ALAT WUDHU OTOMATIS BERBASIS ARDUINO UNO DI MESJID AL ICHSAN GORONTALO

[7] Haryanto, D.P. and Cuswanto, A., 2010. Otomatisasi Pengisian Penampung Air Berbasis Mikrokontroller AT8535. Tugas Akhir Jurusan Teknik Informatika STMIK AMIKOM Yogyakarta. 
[8] Muchlis, M., 2012. Perancangan Dan Pembuatan Alat Pengisi Air Minum Otomatis Dengan Menggunakan Mikrokontroller.

[9] Besari, A.R.A., Zamri, R., Yusaeri, A., Palil, M.D.M. and Prabuwono, A.S., 2009, October. Automatic ablution machine using vision sensor. In 2009 IEEE Symposium on Industrial Electronics \& Applications (Vol. 1, pp. 506-509). IEEE.

[10] Yunardi, R.T., 2017. Analisa Kinerja Sensor Inframerah dan Ultrasonik untuk Sistem Pengukuran Jarak pada Mobile Robot Inspection. Setrum: Sistem Kendali-Tenaga-elektronikatelekomunikasi-komputer, 6(1), pp.33-41.

[11] Benet, G., Blanes, F., Simó, J.E. and Pérez, P., 2002. Using infrared sensors for distance measurement in mobile robots. Robotics and autonomous systems, 40(4), pp.255-266.

[12] Rahman, S.M., Al Mamun, M.A., Ahamed, N.U., Ahmed, N., Ali, M.S. and Islam, M.M., 2014, December. Design of automatic controlling system for tap-water using floatless level sensor. In 2014 IEEE International Symposium on Robotics and Manufacturing Automation (ROMA) (pp. 18-21). IEEE.

[13] Gunturi, V.N.R., 2013. Micro controller based automatic plant irrigation system. International Journal of Advancements in Research \& Technology, 2(4), pp.194-198.

[14] Reza, S.K., Tariq, S.A.M. and Reza, S.M., 2010, October. Microcontroller based automated water level sensing and controlling: design and implementation issue. In Proceedings of the world congress on engineering and computer science (Vol. 1, pp. 20-22). 